\title{
KETERAMPILAN WIRAUSAHA UNTUK KEBERHASILAN USAHA
}

\author{
Sunan Purwa Aji \\ Universitas Pendidikan Indonesia \\ sunan.purwa.aji@student.upi.edu \\ Hari Mulyadi \\ Universitas Pendidikan Indonesia \\ harimulyadi@upi.edu \\ Bambang Widjajanta \\ Universitas Pendidikan Indonesia \\ bambangwidjajanta@upi.edu
}

\begin{abstract}
ABSTRAK
Tujuan - untuk mengetahui gambaran keterampilan wirausaha terhadap keberhasilan usaha.

Desain/metodologi/pendekatan - penelitian ini dilakukan pada rentang waktu kurang dari satu tahun, maka desain penelitian yang digunakan adalah cross sectional method. Penelitian ini menggunakan pendekatan verifikatif dengan metode explanatory survei. Sebanyak 34 responden sebagai sampel menggunakan sampel jenuh. Angket penelitian digunakan sebagai instrument penelitian untuk mengumpulkan data dari responden serta teknik analisis data yang digunakan adalah regresi linear sederhana.

Temuan - keterampilan wirausaha berpengaruh secara signifikan terhadap keberhasilan usaha.

Orisinalitas - perbedaan ditemukan dalam variabel independen, objek dan metode penelitian, populasi dan sampel penelitian, periode penelitian, alat ukur dan hasil penelitian, serta sumber teori dan jurnal asing dan buku.
\end{abstract}

Kata kunci : Keterampilan Wirausaha, Keberhasilan Usaha

Tipe artikel : Penelitian

\section{ABSTRACT}

Objective - to know the description of entrepreneurial skills to business success.

The design / methodology / approach - this study was conducted over a period of less than one year, the research design used was cross sectional method. This research uses verifikatif approach with explanatory survey method. A total of 34 respondents as samples using saturated samples. Questionnaire research is used as a research instrument to collect data from respondents and data analysis techniques used are simple linear regression.

Findings - Entrepreneurial skills have a significant effect on business success.

Originality - differences are found in independent variables, research objects and methods, population and sample research, research periods, measurement tools and research results, as well as sources of foreign theories and journals and books.

Keywords: Luxury Brand Perception, Purchase Intention

Type of article: Research

Keywords: Entrepreneurial Skills, Business Success

Type of article: Research

\section{PENDAHULUAN}

Kewirausahaan sebagai suatu kegiatan penting untuk perusahaan, telah diuji menunjukan adanya hubungan positif antara kewirausahaan dan keberhasilan usaha (Zulkifli \& Rosli, 2013). Tujuan utama dari jalannya bisnis untuk membuat keuntungan, meraih kesuksesan, dan memastikan keberadaannya secara terus menerus. Bisnis yang sukses merupakan salah satu hasil atas aset yang digunakan untuk terus berjalan dengan baik (Muhammad Shukri Bakar, 2011).

Tingkat kegagalan usaha kecil masih tinggi di seluruh dunia. Karena kewiraswastaan mengarah pada pertumbuhan ekonomi, kita membutuhkan lebih banyak pengusaha sukses untuk menumbuhkan ekonomi dan meminimalisir 
kegagalan usaha (Shabir Hyder Robert Lussier, 2016). Keberhasilan usaha yang terjadi di negara Thailand mengalami banyak ketidakpastian yang berujung pada kegagalan, terutama pada usaha kecil dan menengah (Chittithaworn, 2011). Di Malaysia UKM mengalami tingkat kegagalan yang tinggi selama lima tahun terakhir (Chong, 2012). Di Australia, tingkat kegagalan UKM dilaporkan 23\% sementara di Malaysia tingkat kegagalannya sangat tinggi yaitu 60 persen (Ahmad, 2009).

Penelitian mengenai keberhasilan usaha, telah banyak dilakukan pada industri usaha kecil dan menengah (Mandah Chidinma. W. A., 2012), dan juga pada bisnis yang baru dimulai (David Smallbone, 2015). Penelitian tentang keberhasilan usaha itu masih penting untuk diteliti karena mampu meningkatkan pertumbuhan ekonomi suatu negara (Shabir Hyder Robert Lussier, 2016). Penelitian tentang keberhasilan usaha pada industri makanan dan minuman juga diteliti oleh Yonk et al (2017). Keberhasilan usaha menjadi bahan perhatian para peneliti seperti yang dilakukan oleh Ahmad Ali Masykuri dan Yoyok Soesatyo (2013) bahwa pengangguran di indonesia masih sangat tinggi hal itu dikarenakan kebehasilan usaha di Indonesia masih kurang terutama pada Usaha Mikro Kecil, dan Menengah (UMKM) baik itu pengetahuan, modal, dan lain-lain seputar bisnis masih kurang.

Keberhasilan usaha biasanya terkait dengan kemampuan pengusaha untuk menciptakan dan mendistribusikan kekayaan, tetapi juga pada diferensiasinya, yang biasanya terkait dengan inovasi (Vala, 2017). Penentu utama keberhasilan usaha terletak pada ada atau tidaknya manajemen strategis yang berkaitan dengan pengaturan tujuan organisasi jangka panjang dan pengembangan yang akan mempertahankan UMKM dalam memenuhi tujuan yang ditetapkan (Aremu, \& Olodo, 2015). Jaringan sosial penciptaan usaha dan pertumbuhan menentukan keberhasilan usaha, dan bahwa jaringan ini bergantung pada kepercayaan antara pengusaha (Batsaikhan, 2016), selain itu kemudahan informasi, sangat penting untuk kelangsungan hidup dan pertumbuhan perusahaan (Hunjra, 2011) Dengan kata lain, keberhasilan usaha sangat penting dalam kelangsungan usaha yang telah dijalankan dan untuk memajukan pertumbuhan ekonomi suatu negara.

Penduduk benua Asia memiliki jumlah populasi sekitar 4,4 milyar jiwa, dengan jumlah penduduk sebanyak itu benua Asia menjadi pangsa pasar yang potensial untuk berbagai industri. Namun penduduk Asia kurang meminati industri seni rupa terutama pada seni lukis, hal ini disebabkan karena kurangnya keinginan konsumen untuk membeli atau mengoleksi lukisan (http://bali.tribunnews.com/2014/11/01/wisatawanasia-kurang-tertarik-beli-lukisan Senin, 25 Desember 2017 jam 13:21). Sebagaimana penelitian yang diakukan oleh Jamil, Anwar, \& Kholiq (2011) bahwa kesenian yang ada sekarang dapat dianggap tidak sesuai dengan obyek dan tujuan dari pembangunan yang sedang dijalankan, sehingga peran pemerintah untuk membesarkan dan melestarikan kesenian pun kurang direalisasikan.

Masih minimnya apresiasi masyarakat terhadap pagelaran seni tari, teater, maupun lukis akibat kurangnya pemahaman akan esensi seni itu sendiri (Retro $\mathrm{H}$, http://www.pikiranrakyat.com/seni-

budaya/2012/05/25/189833/apresiasi-masyarakatterhadap-seni-masih-minim, diakses pada 27 februari 2018 pukul 19:32) .Pertumbuhan yang dialami oleh industri lukisan (industri lainnya) mengalami penurunan yang signifikan tiap tahunnya (2013-2015). Penurunan yang dialami pada industri lainnya sebesar $13,59 \%$. Untuk lebih jelasnya pertumbuhan tiap industri dapat dilihat di tabel berikut.

\begin{tabular}{|c|c|c|c|c|c|c|}
\hline No. & KELOMPOK KOMODITI & 2013 & 2014 & 2015 & $\begin{array}{l}\% \% \\
\text { Perub }\end{array}$ & $\begin{array}{c}96 \\
\text { Peran } \\
2015 \\
\end{array}$ \\
\hline 1 & Pengolahan Kelapa/Kelapa Sawit & $20.660,4$ & $23.711,6$ & $20.746,1$ & $-12,51$ & 19,45 \\
\hline 2 & $\begin{array}{l}\text { Besi Baja, Mesin-mesin } \\
\text { dan Otomotif }\end{array}$ & $14.684,4$ & $15.813,5$ & $14.443,2$ & $-8,67$ & 13,54 \\
\hline 3 & Tekstil & $12.661,7$ & $12.720,3$ & $12.262,6$ & $-3,60$ & 11,50 \\
\hline 4 & Elektronika & $8.520,1$ & $8.066,9$ & $6.903,7$ & $-14,42$ & 6,47 \\
\hline 5 & Pengolahan Karet & $9.724,1$ & $7.497,5$ & $6.171,4$ & $-17,69$ & 5,79 \\
\hline 6 & Kimia Dasar & $5.083,5$ & $5.703,4$ & $4.150,7$ & $-27,22$ & 3,89 \\
\hline 7 & Makanan dan Minuman & $5.379,8$ & $5.554,4$ & $5.597,0$ & 0,77 & 5,25 \\
\hline 8 & Pulp dan Kertas & $5.644,0$ & $5.498,6$ & $5.332,6$ & $-3,02$ & 5,00 \\
\hline 9 & Pengolahan Kayu & $4.727,7$ & $5.202,3$ & $5.186,6$ & $-0,30$ & 4,86 \\
\hline 10 & $\begin{array}{l}\text { Pengolahan Tembaga, } \\
\text { Timah dll. }\end{array}$ & $4.843,5$ & $4.886,4$ & $3.619,3$ & $-25,93$ & 3,39 \\
\hline 11 & $\begin{array}{l}\text { Kulit, Barang Kulit dan } \\
\text { Sepatu/Alas Kaki }\end{array}$ & $3.933,1$ & $4.090,3$ & $4.615,4$ & 12,84 & 4,33 \\
\hline 12 & $\begin{array}{l}\text { Peng. Emas, Perak, Logam } \\
\text { Mulia, Perhiasan dll. }\end{array}$ & $2.031,2$ & $3.671,8$ & $4.721,7$ & 28,60 & 4,43 \\
\hline & 12 Besar Hasil Industri & $97.893,5$ & $102.416,9$ & $93.750,4$ & $-8,46$ & 87,92 \\
\hline & Industri Lainnya & $15.136,4$ & $14.913,0$ & $12.886,5$ & $-13,59$ & 12,08 \\
\hline & INDUSTRI PENGOLAHAN & $113.029,9$ & \begin{tabular}{ll|l}
$117.330,0$ & 1 \\
\end{tabular} & $106.636,8$ & $-9,11$ & 100,00 \\
\hline
\end{tabular}

Sumber : Laporan Kementrian Perindustrian Republik Indonesia Tahun 2015

Tidak semua komoditas subsektor-subsektor ekraf ada dalam seri data ekspor Indonesia. Selama periode 2010-2016 hanya ada tujuh subsektor ekraf yang komoditasnya diekspor ke luar negeri yaitu film animasi dan video, kriya, kuliner, musik, fashion, penerbitan, dan seni rupa. Berikut adalah data mengenai ekspor ekonomi kreatif menurut subsektor dari tahun 2010-2016 : 


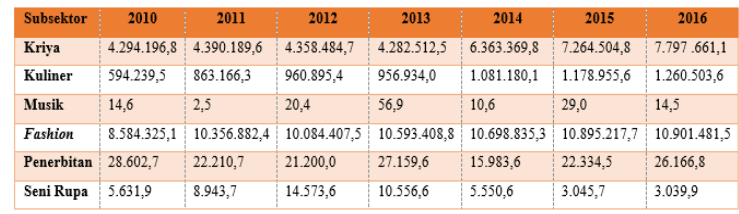

Sumber : BEKRAF Ekspor ekonomi kreatif 2010-2016 (Dokumen PEB dan Non-PEB, diolah)

Tabel diatas menunjukkan bahwa dibandingkan dengan industri lainnya seperti kriya, kuliner,fashion dan penerbitan terjadinya penurunan yang dialami subsektor seni rupa sangat lah signifikan dari tahun 2012-2016 dengan total nilai ekspor dari 14.573.600 US\$ menjadi 3.039.900 US\$ hanya dalamkurun waktu empat tahun berturut-turut.

Penelitian yang dilakukan oleh Ina Primiana, dkk (2009) menyatakan bahwa keberhasilan usaha yang terjadi pada UMKM di jawa barat dikarenakan banyaknya hambatan yang terjadi. UMKM masih dihadapi oleh keterbatasan untuk menembus perijinan, permasalahan SDM, pasar, akses permodalan, inovasi, kualitas produk dan minimnya pertimbangan faktor lingkungan dan sosial untuk memasuki pasar ekspor. Dan cara menanggulanginya adalah dengan cara membuat banyak wirausaha di Indonesia untuk menciptakan banyak lapangan kerja dan mengurangi jumlah pengangguran. Sedangkan menurut Hari Mulyadi, (2010) Keberhasilan dalam mencapai tujuan perusahaan sangat ditentukan oleh kinerja karyawannya

Menurut Henry Faizal Noor (2008) mengemukakan bahwa keberhasilan usaha terdiri dari 5 indikator yaitu 1). Laba, 2). Produktifitas dan efisiensi, 3). Daya saing, 4). Kompetensi dan etika usaha, dan 5). Terbangunnya citra yang baik.

Berdasarkan rumusan masalah di atas, maka tujuan penelitian ini adalah untuk memperoleh hasil temuan mengenai: (1) memperoleh temuan gambaran keterampilan wirausaha, (2) memperoleh temuan gambaran keberhasilan usaha,

\section{KAJIAN PUSTAKA}

Kewirausahaan merupakan orang-orang yang mempunyai insting (semangat, jiwa, nalar, intuisi, dan kompetensi), untuk berbisnis, risk taker (pengambilan resiko), berani investasi, berani rugi dalam memperoleh keuntungan (gambling) dan berani melakukan perubahan dengan cepat dan besar (bila memang dibutuhkan) untuk menciptakan kemajuan setiap saat. (Z. Heflin Frinces, 2011).

Kewirausahaan adalah kemampuan kreatif dan inovatif yang dijadikan dasar, kiat dan sumber daya untuk mencari peluang menuju sukses.Adapun inti dari kewirausahaan adalah kemampuan untuk menciptakan sesuatu yang baru dan berbeda (create new and different) melalui berpikir kreatif dan bertindak inovatif untuk menciptakan peluang (Suryana, 2003). Menurut Guido Corbetta (2004:18) kewirausahaan adalah tentang mengantisipasi pasar dengan tepat. Jika pengusaha berhasil dalam mengantisipasi pasar, dia akan dapat menghasilkan produk lebih murah dari pada pesaing dan mendapatkan keuntungan dengan menjadi berguna dan bermanfaat bagi pelanggan, maka semakin banyak keuntungan yang akan didapat. Kewirausahaan terutama ditandai oleh ketidakpastian, situasi yang tidak terkendali dan tidak dapat dinilai dalam hal probabilitas. Keuntungan yang diperoleh pengusaha adalah imbalan atas pengambilan risikonya dalam kondisi ketidakpastian. Kewirausahaan adalah kekuatan untuk berinovasi, kohesif, dan berimbang yang dampaknya ekonomi pasar dapat terus berjalan. Keuntungan diperoleh para pengusaha tetapi hal ini tidak dapat dikaitkan dengan nilai sumber daya apapun, namun merupakan imbalan kewaspadaan, karena membuat dugaan yang benar. Kewirausahaan juga memiliki beberapa bagian dimana salahsatunya terdapat karakteristik wirausaha yang terdiri dari karakteristik umum, karakteristik wirausaha sukses, dan karakteristik wirausaha gagal. Beberapa hasil studi telah menunjukkan beberapa sebab bagaimana atau mengapa seorang wirausaha sukses yaitu 1). Kerja keras, 2). Permintaan pasar, 3). Keterampilan wirausaha, 4). Keberuntungan, 5). Keberanian dalam mengambil resiko, 6). Tingginya kebutuhan otonomi, 7). Mandiri, 8). Percaya diri, 9). Tidak mudah menyerah, dan 10). Berambisi. (Z. Heflin Frinces, 2011).

Nkansah (2011:1) mengemukakan beberapa teori yang telah dikemukakan oleh para ilmuwan untuk menjelaskan bidang kewirausahaan. Teori-teori ini berakar pada ekonomi, psikologi, sosiologi, antropologi, dan manajemen.

\section{Economic Entrepreneurship Theories}

Teori kewirausahaan ekonomi memiliki akar yang dalam pada teori ekonomi klasik dan neoklasik, dan proses pasar Austria (AMP). Teori-teori ini mengeksplorasi faktor ekonomi yang meningkatkan perilaku kewirausahaan.

a. Teori Klasik (Classical Theory)

Teori klasik memuji kebijakan perdagangan bebas, spesialisasi, dan persaingan (Ricardo, 1817) dan (Smith, 1776). Teori ini adalah hasil revolusi industri Inggris yang berlangsung pada pertengahan 1700 dan berlangsung sampai tahun 1830. Gerakan klasik tersebut menggambarkan peran pengarah pengusaha dalam konteks produksi dan distribusi 
barang di pasar yang kompetitif (Say, 1803). Ahli teori klasik mengartikulasikan tiga mode produksi yaitu tanah, modal, dan tenaga kerja.

b. Teori Neoklasik (Neo-classical Theory)

Model neo-klasik muncul dari kritik model klasik dan menunjukkan bahwa fenomena ekonomi dapat diturunkan ke contoh pertukaran murni, mencerminkan rasio optimal, dan terjadi dalam sistem ekonomi yang pada dasarnya ditutup. Sistem ekonomi terdiri dari peserta pertukaran, pertukaran kejadian, dan dampak hasil pertukaran pelaku pasar lainnya. Pentingnya pertukaran ditambah dengan utilitas marjinal yang semakin sedikit menciptakan dorongan bagi kewiraswastaan dalam gerakan neoklasik (Murphy, J.P, Liao, J \& Welsch, 2006).

Beberapa kritik diajukan terhadap dugaan neo-klasik. Pertama adalah bahwa permintaan agregat mengabaikan keunikan aktivitas kewirausahaan pada tingkat individu. Kedua, baik nilai tukar maupun nilai tukar mencerminkan nilai inovasi di masa depan. Ketiga, alokasi sumber daya rasional tidak menangkap kompleksitas sistem berbasis pasar. Poin keempat yang diangkat adalah bahwa, kinerja berbasis efisiensi tidak memasukkan inovasi dan keluaran yang tidak seragam. Cara / ujung yang diketahui dan pengetahuan sempurna atau semi-sempurna tidak menggambarkan ketidakpastian. Selain itu, persaingan sempurna tidak memungkinkan inovasi dan aktivitas kewirausahaan. Poin kelima adalah bahwa, tidak mungkin untuk melacak semua input dan output dalam sistem pasar. Akhirnya, aktivitas kewirausahaan dapat merusak tata tertib pada sistem ekonomi.

\section{c. Austrian Market Process (AMP)}

Pertanyaan yang tidak terjawab dari gerakan neoklasik ini menghasilkan sebuah gerakan baru yang kemudian dikenal sebagai the Austrian Market Process (AMP). AMP, model yang dipengaruhi oleh berkonsentrasi pada tindakan manusia dalam konteks ekonomi pengetahuan. Schumpeter (1934) Menggambarkan kewiraswastaan sebagai pendorong sistem berbasis pasar. Dengan kata lain, fungsi penting suatu perusahaan adalah menciptakan sesuatu yang baru yang menghasilkan proses yang berperan sebagai dorongan bagi gerak ekonomi pasar.

Menurut Murphy, J.P, Liao, J \& Welsch (2006) berpendapat bahwa gerakan tersebut menawarkan logika realitas dinamis. Dalam menjelaskan hal ini, mereka menunjukkan fakta bahwa pengetahuan dikomunikasikan ke seluruh sistem pasar (misalnya melalui informasi harga), inovasi terjadi, pengusaha memenuhi kebutuhan pasar, dan perubahan tingkat sistem terjadi. Jika seorang wirausahawan tahu cara membuat barang atau jasa baru, atau mengetahui cara yang lebih baik untuk melakukannya, manfaat bisa didapat melalui pengetahuan ini. Pengusaha memberdayakan pengetahuan ketika mereka yakin akan memperoleh beberapa keuntungan yang ditentukan secara individu.

Kerangka neoklasik sebelumnya tidak menjelaskan kegiatan tersebut; Ini diasumsikan persaingan sempurna, membawa asumsi sistem tertutup, menelusuri data fakta yang dapat diamati, dan menyimpulkan asas observasi berbasis observasi. Sebaliknya, AMP menolak anggapan bahwa keadaan berulang, selalu mengarah pada hasil yang sama dalam sistem ekonomi. Sebaliknya, pengusaha pengusaha diberi insentif untuk menggunakan pengetahuan episodik (yaitu, mungkin tidak pernah terlihat sebelumnya dan tidak pernah terlihat lagi), untuk menghasilkan nilai.

AMP didasarkan pada tiga konseptualisasi utama (Kirzner, 1973). Yang pertama adalah pasar arbitrase di mana peluang muncul bagi pelaku pasar tertentu karena orang lain mengabaikan peluang tertentu atau melakukan aktivitas suboptimal. Yang kedua adalah kewaspadaan terhadap peluang menghasilkan keuntungan, yang ditemukan pengusaha dan keuntungan kewirausahaan. Konseptualisasi ketiga, berikut menurut Say (1803) dan Schumpeter (1934), adalah bahwa kepemilikan berbeda dari kewiraswastaan. Dengan kata lain, kewiraswastaan tidak memerlukan kepemilikan sumber daya, sebuah gagasan yang menambahkan konteks pada ketidakpastian dan risiko. Konseptualisasi ini menunjukkan bahwa setiap kesempatan unik dan oleh karena itu aktivitas sebelumnya tidak dapat digunakan untuk memprediksi hasil secara handal.

Model AMP bukan tanpa kritik. Kritik pertama adalah bahwa sistem pasar tidak sepenuhnya kompetitif namun dapat melibatkan kerja sama antagonis. Yang kedua adalah monopoli sumber daya dapat menghambat persaingan dan kewirausahaan. Yang ketiga adalah bahwa kecurangan / penipuan dan pajak / kontrol juga berkontribusi terhadap aktivitas sistem pasar. Yang keempat adalah perusahaan swasta dan negara berbeda tapi keduanya bisa berwirausaha dan kelima, kewiraswastaan bisa terjadi dalam situasi sosial non-pasar tanpa persaingan. Kritik terhadap AMP telah memberi dorongan pada penjelasan terakhir dari psikologi, sosiologi, antropologi, dan manajemen.

Model AMP bukan tanpa kritik. Kritik pertama adalah bahwa sistem pasar tidak sepenuhnya kompetitif namun dapat melibatkan kerja sama antagonis. Yang kedua adalah monopoli sumber 
daya dapat menghambat persaingan dan kewirausahaan. Yang ketiga adalah bahwa kecurangan / penipuan dan pajak / kontrol juga berkontribusi terhadap aktivitas sistem pasar. Yang keempat adalah perusahaan swasta dan negara berbeda tapi keduanya bisa berwirausaha dan kelima, kewiraswastaan bisa terjadi dalam situasi sosial non-pasar tanpa persaingan.. Kritik terhadap AMP telah memberi dorongan pada penjelasan terakhir dari psikologi, sosiologi, antropologi, dan manajemen

2. Psychological Entrepreneurship Theories Tingkat analisis dalam teori psikologis adalah individu (Landstrom, 1998). Teori-teori ini menekankan karakteristik pribadi yang mendefinisikan kewiraswastaan. Sifat kepribadian yang dibutuhkan untuk pencapaian dan lokus kontrol ditinjau dan bukti empiris disajikan untuk tiga karakteristik baru lainnya yang telah ditemukan terkait dengan kecenderungan kewiraswastaan. Ini adalah pengambilan risiko, inovasi, dan toleransi terhadap ambiguitas. Bagi para teoretikus karakteristik ada kualitas lahir tua atau potensi individu yang secara alami membuatnya menjadi pengusaha. Pertanyaan yang jelas atau logis di benak Anda mungkin adalah "Apa ciri khas / kualitas bawaan?" Jawabannya bukanlah jawaban yang lurus karena kita tidak bisa menunjukkan ciriciri tertentu. Namun, model ini memberikan beberapa wawasan tentang sifat atau kualitas bawaan ini dengan mengidentifikasi karakteristik yang terkait dengan wirausahawan. Ciri-ciri memberi kita petunjuk atau pemahaman tentang sifat atau potensi bawaan ini. Sebenarnya, menjelaskan sifat kepribadian berarti membuat kesimpulan dari perilaku.

Beberapa karakteristik atau perilaku yang terkait dengan wirausahawan adalah bahwa mereka cenderung lebih didorong oleh kesempatan, menunjukkan tingkat kreativitas dan inovasi yang tinggi, dan menunjukkan tingkat keterampilan manajemen dan pengetahuan bisnis yang tinggi. Mereka juga terbukti optimis, (mereka melihat cangkir itu setengah penuh dari setengah kosong), tahan emosi dan memiliki energi mental, mereka adalah pekerja keras, menunjukkan komitmen dan ketekunan yang kuat, berkembang pada keinginan kompetitif untuk berprestasi dan menang, cenderung tidak puas dengan status quo dan keinginan perbaikan, pengusaha juga bersifat transformasional, yaitu pembelajar seumur hidup dan menggunakan kegagalan sebagai alat dan batu loncatan. Mereka juga percaya bahwa mereka secara pribadi dapat membuat perbedaan, adalah orang-orang yang memiliki integritas dan terutama visioner.

Model trait masih belum didukung oleh bukti penelitian. Satu-satunya cara untuk menjelaskan atau mengklaim bahwa itu ada adalah melihat melalui lensa karakteristik / perilaku seseorang dan menyimpulkan bahwa seseorang memiliki kualitas bawaan untuk menjadi pengusaha.

\section{a. Locus of Control}

Locus of control adalah aspek penting kepribadian. Konsep ini pertama kali diperkenalkan oleh Julian Rotter di tahun 1950an. Mengacu pada Locus of Control sebagai persepsi individu tentang penyebab utama peristiwa dalam hidupnya (Rotter, 1966). Dengan kata lain, orientasi locus of control adalah kepercayaan tentang apakah hasil tindakan kita bergantung pada apa yang kita lakukan (orientasi pengendalian internal) atau pada kejadian di luar kendali pribadi kita (orientasi kontrol eksternal).

Dalam konteks ini, kesuksesan pengusaha berasal dari kemampuannya sendiri dan juga dukungan dari luar. Yang pertama disebut sebagai lokus kontrol internal dan yang terakhir disebut sebagai lokus kontrol eksternal. Sementara individu dengan lokus kontrol internal percaya bahwa mereka dapat mengendalikan kejadian hidup, individu dengan lokus kontrol eksternal percaya bahwa kejadian hidup adalah hasil dari faktor eksternal, seperti kebetulan, keberuntungan atau takdir.

\section{$b$. Need for Achievement theory}

Sementara model sifatnya berfokus pada kualitas bawaan lahir muda dan lokus kontrol terhadap persepsi individu tentang penghargaan dan hukuman dalam hidupnya. Pengusaha didorong oleh kebutuhan untuk mencapainya dan berprestasi. Meskipun tidak ada bukti penelitian untuk mendukung ciri kepribadian, ada bukti hubungan antara motivasi berprestasi dan kewirausahaan (Johnson, 1990). Motivasi berprestasi mungkin merupakan satu-satunya faktor personifikasi yang meyakinkan terkait penciptaan usaha baru.

Mengambil risiko dan berinovasi, kebutuhan akan prestasi, dan toleransi terhadap ambiguitas memiliki pengaruh positif dan signifikan terhadap kecenderungan kewirausahaan. Namun, locus of control (LOC) memiliki pengaruh negatif terhadap kecenderungan wirausaha. Lokakarya pengendalian juga ditemukan sangat berkorelasi dengan variabel seperti pengambilan risiko, kebutuhan akan pencapaian, dan toleransi terhadap ambiguitas. Temuan baru-baru ini tentang pengambilan risiko memperkuat studi empiris sebelumnya yang menunjukkan bahwa keengganan untuk mengambil risiko menurun seiring dengan kenaikan kekayaan, 
yaitu aset bersih dan nilai pendapatan masa depan (Szpiro, 1986).

\section{Sociological Entrepreneurship Theory}

Teori sosiologis adalah teori kewiraswastaan ketiga yang utama. Perusahaan sosiologis berfokus pada konteks sosial. Dengan kata lain, dalam teori sosiologis tingkat analisis secara tradisional adalah masyarakat (Landstrom, 1998). Menurut Reynolds (1991) telah mengidentifikasi empat konteks sosial yang berkaitan dengan peluang kewirausahaan. Yang pertama adalah jaringan sosial. Di sini, fokusnya adalah membangun hubungan sosial dan ikatan yang mempromosikan kepercayaan dan bukan oportunisme. Dengan kata lain, pengusaha seharusnya tidak mengambil keuntungan yang tidak semestinya dari orang-orang agar sukses. Sebaliknya kesuksesan datang sebagai hasil dari menjaga kepercayaan dengan orang-orang.

Yang kedua ia menyebut konteks tahap kehidupan yang melibatkan analisis situasi kehidupan dan karakteristik individu yang telah memutuskan untuk menjadi pengusaha. Pengalaman orang bisa mempengaruhi pemikiran dan tindakan mereka sehingga mereka ingin melakukan sesuatu yang berarti dengan kehidupan mereka.

Konteks ketiga adalah identifikasi etnis. Latar belakang sosiologis seseorang adalah salah satu faktor "dorongan" yang menentukan untuk menjadi pengusaha. Misalnya, latar belakang sosial seseorang menentukan seberapa jauh dia bisa pergi. Kelompok marjinal mungkin melanggar semua rintangan dan berusaha meraih kesuksesan, didorong oleh latar belakang mereka yang kurang beruntung untuk membuat hidup lebih baik. Konteks sosial keempat disebut ekologi populasi. Idenya adalah faktor lingkungan memainkan peran penting dalam kelangsungan usaha. Sistem politik, peraturan pemerintah, pelanggan, karyawan dan persaingan adalah beberapa faktor lingkungan yang mungkin berdampak pada kelangsungan usaha baru atau keberhasilan pengusaha.

\section{Anthropological Entrepreneurship Theory}

Teori utama keempat disebut sebagai teori antropologi. Antropologi adalah studi tentang asal mula, perkembangan, kebiasaan, dan kepercayaan suatu komunitas. Dengan kata lain, budaya masyarakat di masyarakat. Teori antropologi mengatakan bahwa bagi seseorang yang berhasil memulai usaha, konteks sosial dan budaya harus diperiksa atau dipertimbangkan.

Disini penekanannya adalah pada model kewirausahaan budaya. Model tersebut mengatakan bahwa usaha baru diciptakan oleh pengaruh budaya seseorang. Praktik budaya mengarah pada sikap kewirausahaan seperti inovasi yang juga berujung pada perilaku penciptaan usaha. Kebangsaan individu mempengaruhi sikap dan perilaku dan budaya mencerminkan kompleksitas etnis, sosial, ekonomi, ekologi, dan politik tertentu pada individu. Dengan demikian, lingkungan budaya dapat menghasilkan perbedaan sikap serta perbedaan perilaku kewirausahaan.

\section{Opportunity-Based Entrepreneurship}

Theory

Teori berbasis kesempatan ini dilambangkan dengan nama-nama seperti Peter Drucker dan Howard Stevenson. Pendekatan berbasis kesempatan menyediakan kerangka konseptual luas untuk penelitian kewiraswastaan. Lebih lanjut dia mengatakan, "Ini mendefinisikan pengusaha dan kewiraswastaan, pengusaha selalu mencari perubahan, meresponsnya, dan memanfaatkannya sebagai sebuah peluang". Kesempatan membangun pengusaha memiliki lebih banyak mata untuk kemungkinan yang diciptakan karena perubahan daripada masalah. Hal ini didasarkan pada penelitian untuk mengetahui perbedaan antara manajemen kewirausahaan dan pengelolaan administrasi. Dia menyimpulkan bahwa pusat pengelolaan kewirausahaan adalah "mengejar kesempatan tanpa memperhatikan sumber daya yang saat ini dikendalikan".

\section{Resource- Based Entrepreneurship Theories}

Teori kewiraswastaan berbasis sumber daya berpendapat bahwa akses terhadap sumber daya oleh para pendiri merupakan prediktor penting dari kewirausahaan berbasis peluang dan pertumbuhan usaha baru (Alvarez \& Barney, 2007). Teori ini menekankan pentingnya sumber daya keuangan, sosial dan manusia (Aldrich, 2006). Modal keuangan, sosial dan manusia mewakili tiga kelas teori berdasarkan teori kewiraswastaan berbasis sumber daya.

\section{a. $\quad$ Financial Capital/Liquidity Theory}

Penelitian empiris telah menunjukkan bahwa pendirian perusahaan baru lebih umum terjadi ketika orang memiliki akses terhadap modal finansial. Dengan implikasi teori ini menunjukkan bahwa orang dengan modal finansial lebih mampu memperoleh sumber daya untuk mengeksploitasi peluang kewiraswastaan secara efektif, dan membuat perusahaan untuk melakukannya (Clausen, 2006). Hal ini disebabkan oleh fakta bahwa garis penelitian yang terkait dengan teori batasan likuiditas pada umumnya bertujuan untuk menentukan apakah akses pendiri terhadap modal ditentukan oleh jumlah modal yang digunakan untuk memulai usaha baru. Menurutnya, ini tidak 
selalu mengesampingkan kemungkinan memulai sebuah firma tanpa banyak modal. Oleh karena itu, akses pendiri ke modal merupakan prediktor penting pertumbuhan usaha baru namun belum tentu penting untuk pendirian usaha baru (Lusardi, 2004)

Teori ini berpendapat bahwa pengusaha memiliki sumber daya spesifik individu yang memfasilitasi pengakuan peluang baru dan perakitan sumber daya baru untuk perusahaan yang baru muncul (Alvarez \& Barney, 2007). Penelitian menunjukkan bahwa beberapa orang lebih mampu mengenali dan memanfaatkan peluang daripada yang lain karena mereka memiliki akses terhadap informasi dan pengetahuan yang lebih baik.

b. Social Capital or Social Network Theory

Pengusaha tertanam dalam struktur jaringan sosial yang lebih besar yang merupakan proporsi signifikan dari struktur kesempatan mereka (Clausen, 2006). Shane (2003) mengatakan bahwa seorang individu mungkin memiliki kemampuan untuk mengenali bahwa ada peluang kewiraswastaan yang ada, namun mungkin tidak memiliki hubungan sosial untuk mengubah kesempatan menjadi bisnis yang dimulai. Diperkirakan bahwa akses ke jaringan sosial yang lebih besar dapat membantu mengatasi masalah ini. Literatur mengenai teori ini menunjukkan bahwa hubungan sosial yang lebih kuat dengan penyedia sumber daya memfasilitasi perolehan sumber daya dan meningkatkan probabilitas eksploitasi peluang (Zimmer, 1986).

c. Human Capital Entrepreneurship Theory

Yang mendasari teori kewirausahaan modal manusia adalah dua faktor, pendidikan dan pengalaman. Pengetahuan yang diperoleh dari pendidikan dan pengalaman merupakan sumber yang didistribusikan secara heterogen ke seluruh individu dan pada dasarnya penting untuk memahami perbedaan dalam identifikasi dan eksploitasi peluang. studi empiris menunjukkan bahwa faktor modal manusia secara positif terkait dengan menjadi wirausahawan yang baru lahir meningkatkan pengenalan peluang dan bahkan kesuksesan kewirausahaan (Becker, 1975).

Karakteristik wirausaha terdiri dari 3 jenis, karakteristik umum, karakteristik wirausaha sukses, karakteristik wirausaha gagal (Z. Heflin Frinces, 2011).

Keterampilan wirausaha sangat penting, karena konsep keterampilan menyiratkan kemungkinan belajar, dan mengajar. Dalam literatur psikologis tentang kewirausahaan, dan juga beberapa teori oleh ekonom, pengusaha sering digambarkan sebagai individu dengan karakteristik dan fitur yang stabil dan bertahan lama. Penekanannya adalah pada ciri kepribadian (Brockhaus, R.H. and Horwitz, 1986). Menurut Smilor (1997) dan Kilby (1971) keterampilan kewirausahaan mengacu pada aktivitas, atau pengetahuan praktis, yang dibutuhkan untuk membangun dan menjalankan bisnis dengan sukses. Ini mungkin terdiri dari area keuangan, akuntansi, pemasaran atau produksi. Banyak orang lain ingin membedakan antara keterampilan manajerial dan kewirausahaan. Sebagai contoh, Chen, C.C., et al (1998) menulis bahwa banyak kursus sekolah bisnis, "berfokus pada keterampilan manajemen yang teridentifikasi, namun sering mengabaikan keterampilan kewirausahaan seperti inovasi dan pengambilan risiko". Namun penelitian yang dilakukan Timmons (1999), dosen pendidikan kewirausahaan di AS mengatakan "Kewirausahaan adalah cara berpikir, penalaran dan akting yang merupakan kesempatan terobsesi".

Kewirausahaan menjadi hal yang sangat penting dan telah diteliti oleh banyak ahli teori karena kontribusi positifnya terhadap kehidupan ekonomi dan sosial. Terdapat dua sudut pandang yang berkembang dalam mendefinisikan kewirausahaan. Pertama disebut sebagai sekolah ekonomi. Pengusaha menciptakan nilai melalui eksplorasi, inovasi, berpikir kreatif dan dengan menemukan produk, layanan, sumber, teknologi dan pasar baru. Memahami kewirausahaan terutama yang berkaitan dengan individu dan proses perilaku (Geri, 2013).

Keterampilan usaha menjadi suatu perdebatan apakah kewirausahaan bisa dipahami sebagai sesuatu yang bisa diajarkan atau tidak (Jarkko Pyysiainen, 2014). Menurut Katz (1991) mengemukakan bahwa kemungkinan besar ada beberapa keterampilan yang bisa diajarkan dan beberapa hal yang tidak bisa diajarkan. Chen, C.C., et al (1998) membedakan enam jenis peran atau tugas kewirausahaan yaitu pemasaran, inovasi, manajemen, pengambila resiko dan pengendalian keuangan.

Keterampilan diartikan sebagai kemampuan seseorang terhadap suatu hal meliputi tentang kecakapan, sikap, nilai, dan pengertian yang semuanya dipertimbangkan sebagai sesuatu yang penting untuk menunjang keberhasilan didalam penyelesaian tugas (Yanto, 2005) dalam (Nafuroh, 2013). Keterampilan adalah pola kegiatan yang bertujuan untuk memanipulasi dan mengkoordinasi informasi. Keterampilan ini dapat dibedakan menjadi dua kategori, yakni keterampilan fisik dan keterampilan intelektual (Sutarna, 2016). 
Keterampilan berasal dari kata terampil yang berarti cakap, mampu, dan cekatan. Menurut Iverson (2001) mengatakan keterampilan membutuhkan pelatihan dan kemampuan dasar yang dimiliki setiap orang dapat lebih membantu menghasikan sesuatu yang lebih bernilai dengan lebih cepat.

Keterampilan usaha hal-hal yang berkaitan untuk menciptakan atau inovasi bisnis, menumbuhkembangkan unit usaha yang sudah berjalan, dan melakukan penyehatan unit usaha yang mengalami krisis (Z. Heflin Frinces, 2011). Robbins (2006) mengatakan keterampilan dibagi menjadi 4 kategori, yaitu 1). Basic Literacy Skill, keahlian dasar yang sudah pasti harus dimiliki oleh setiap orang seperti membaca, menulis, berhitung serta mendengarkan. 2). Technical Skill, keahlian secara teknis yang didapat melalui pembelajaran dalam bidang teknik seperti mengoperasikan kompter dan alat digital lainnya. 3). Interpersonal Skill, keahlian setiap orang dalam melakukan komunikasi satu sama lain seperti mendengarkan seseorang, memberi pendapat dan bekerja secara tim. 4). Problem Solving, keahlian seseorang dalam memecahkan masalah dengan menggunakan logika atau perasaanya.

Menurut Z. Heflin Frinces (2011) bahwa keterampilan wirausaha terdiri dari 3 hal yaitu keterampilan teknis, keterampilan manajemen bisnis dan keterampilan kewirausahaan personal. Fitriati \& Hermiati (2010) mengatakan bahwa keterampilan wirausaha memiliki tiga dimensi yaitu 1). Technical Skill, 2). Business Management Skill, 3). Personal Entrepreneurial Skills.

Keberhasilan usaha didorong oleh orientasi kewirausahaan (Covin, 1991), keberhasilan usaha biasanya merupakan hasil dari cara berbisnis dan kerjasama. Kerjasama antar perusahaan, konsultasi, pengukuran kinerja, dan fleksibilitas dapat memainkan peran penting dalam kesuksesan bisnis. Kerjasama antar perusahaan memberikan kontribusi positif untuk mendapatkan legitimasi organisasi dan untuk mengembangkan reputasi pasar yang diinginkan. Kerjasama juga memungkinkan perusahaan kecil untuk memperbaiki posisi strategisnya, fokus pada bisnis intinya, memasuki pasar internasional, mengurangi biaya transaksi, mempelajari keterampilan baru, dan mengatasi perubahan teknologi yang cepat (Chittithaworn, 2011). Keberhasilan usaha adalah kemampuan bisnis untuk mencapai tujuannya. Ini adalah pencapaian bisnis berkaitan dengan tujuan bisnisnya (Muhammad Shukri Bakar, 2011). Menurut Henry Faizal Noor (2008) juga mengemukakan bahwa keberhasilan usaha pada hakikatnya adalah keberhasilan dari bisnis mencapai tujuannya. Suatu bisnis dikatakan berhasil bila mendapat laba, karena laba adalah tujuan orang melakukan bisnis. Keberhasilan usaha adalah kemampuan perusahaan untuk menciptakan dan mendistribusikan kekayaan, tetapi juga pada diferensiasinya, yang biasanya terkait dengan inovasi (Ketchen, Ireland, \& Snow, 2007). Menurut Purnama (2010) keberhasilan usaha pada industri kecil di pengaruhi oleh berbagai faktor. Keberhasilan usaha pada perusahaan merupakan salah satu tujuan dari setiap pengusaha. Keberhasilan usaha industri kecil dapat diartikan sebagai tingkat keberhasilan dalam pencapaian maksud atau tujuan yang diharapkan. Sebagai ukuran keberhasilan usaha suatu perusahaan dapat dilihat dari berbagai aspek, seperti kinerja keuangan dan image perusahaan. Menurut Ina Primiana, dkk (2009) mengemukakan bahwa, keberhasilan usaha adalah permodalan sudah terpenuhi, penyaluran yang produktif dan tercapainya tujuan organisasi. Menurut Algifari (2003) mengatakan bahwa, keberhasilan usaha dapat dilihat dari efisiensi proses produksi yang dikelompokkan berdasarkan efisiensi secara teknis dan efisiensi secara ekonomis. Henry Faizal Noor (2008) Mengemukakan bahwa keberhasilan usaha pada hakikatnya adalah keberhasilan dari bisnis mencapai tujuannya, suatu bisnis dikatakan berhasil bila mendapat laba, karena laba adalah tujuan dari seseorang melakukan bisnis. Sedangkan Dwi Riyanti (2003) Mengemukakan bahwa keberhasilan usaha didefinisikan sebagai tingkat pencapaian hasil atau tujuan organisasi.

Fry F.L Stoner (1998) menyatakan sejumlah indikator keberhasilan untuk memasukkan kinerja keuangan, kebutuhan dan nilai pelanggan, kualitas produk dan layanan, inovasi dan kreativitas, dan komitmen karyawan. Dwi Riyanti (2003) Mengemukakan bahwa dimensi dalam mengukur keberhasilan usaha, yaitu 1). Peningkatan dalam akumulasi modal atau peningkatan modal, 2). Jumlah produksi, 3). Jumlah pelanggan, 4). Perluasan Usaha, 5). Perluasan daerah pemasaran, 6). Perbaikan saran fisik, dan 7). Pendapatan usaha. Selain itu Henry Faizal Noor (2008) Mengemukakan bahwa dimensi dalam mengukur keberhasilan usaha, yaitu 1). Laba, 2). Produktivitas dan Efisiensi, 3). Daya Saing, 4). Kompetensi dan Etika Usaha, 5). Terbangunnya Citra Yang Baik.

Penelitian yang dilakukan oleh Hunjra (2011), mengatakan bahwa keberhasilan usaha dipengaruhi oleh beberapa faktor seperti sumber daya keuangan, strategi pemasaran, sumber daya tekhnologi, dukungan pemerintah, kemudahan mengakses 
informasi, perencanaan bisnis, dan keterampilan wirausaha. Meurut Chukwujioke (2013) mengemukakan bahwa keberhasilan usaha akan berhasil dengan memiliki keterampilan dalam perencanaan dan penganggaran untuk strategi pemasaran yang menyediakan berbagai produk menarik, bertindak cepat mendeteksi perubahan lingkungan, menilai masalah penjualan sebagai cara mempertahankan hubungan dengan pelanggan, fokus pada kualitas produk sehingga dapat meraih pangsa pasar dan menarik serta mempertahankan karyawan yang kompeten

\section{METODE PENELITIAN}

Penelitian ini menganalisis pengaruh keterampilan wirausaha terhadap keberhasilan usaha. Variabel bebas dalam penelitian ini yaitu keterampilan wirausaha dengan dimensinya yaitu keterampilan teknis, keterampilan manajemen bisnis, dan keterampilan kewirausahaan personal. Serta variabel terikat yaitu keberhasilan usaha dimensinya mencakup laba, produktifitas dan efisiensi, daya saing, kompetensi dan etika usaha, serta terbangunnya citra yang baik.

Berdasarkan tingkat penjelasan dan bidang penelitian, maka jenis penelitian ini adalah penelitian deskriptif Menurut Sugiyono (2011) mengungkapkan bahwa penelitian deskriptif merupakan penelitian yang dilakukan untuk mengetahui nilai variabel mandiri, baik satu variabel atau lebih (independent) tanpa membuat perbandingan atau menghubungkan antara satu dengan variabel yang lain. Tujuan dari penelitian deskriptif adalah membuat deskripsi, gambaran atau lukisan secara sistematis, faktual dan akurat, mengatasi fakta-fakta, sifat-sifat, serta hubungan antara fenomena yang diselidiki. Penelitian deskriftif ini mempunya maksud untuk mengetahui gambaran secara keseluruhan mengenai keterampilan wirausaha dan keberhasilan usaha pada industri lukisan di Jelekong, Kabupaten Bandung.

Berdasarkan jenis penelitian deskriptif yang dilaksanakan melalui pengumpulan data di lapangan, maka metode yang digunakan dalam penelitian ini adalah explanatory survey.

\section{HASIL DAN PEMBAHASAN}

Variabel bebas dalam penelitian ini yaitu keterampilan wirausaha sedangkan untuk variabel terikatnya adalah keberhasilan usaha. Untuk menguji ada tidaknya pengaruh bebas terhadap variabel terikat, dilakukan dengan pengujian regresi sederhana.

\begin{tabular}{|c|c|c|c|c|}
\hline No & Dimensi & Total Skor & Skor Ideal & $\%$ \\
\hline \multicolumn{5}{|c|}{ Keterampilan Wirausaha } \\
\hline 1 & Keterampilan Teknis & 734 & 1428 & 51,4 \\
\hline 2 & $\begin{array}{l}\text { Keterampilan Manajemen } \\
\text { Bisnis }\end{array}$ & 1063 & 2142 & 49,6 \\
\hline 3 & $\begin{array}{l}\text { Keterampilan Kewirausahaan } \\
\text { Personal }\end{array}$ & 379 & 714 & 53,1 \\
\hline & Total & 2176 & 4284 & 50,8 \\
\hline
\end{tabular}

Sumber : Hasil Pengolahan Data 2018

Berdasarkan Gambar dimensi Keterampilan Wirausaha yang skor totalnya tertinggi adalah Keterampilan Wirausaha Personal dengan perolehan skor sebanyak 379 atau 53,1\% sementara dimensi yang skor totalnya terendah adalah Keterampilan Manajemen Bisnis dengan perolehan skor sebanyak 1063 atau 49,6\%. Perolehan skor berdasarkan hasil perolehan data pada variabel keterampilan wirausaha secara keseluruhan adalah 2176, apabila di Persentasekan kedalam skor ideal maka diperoleh Persentase sebesar 50,8\% yang berarti responden menyatakan Keterampilan Wirausaha pada Industri Lukisan di Jelekong, Kabupaten Bandung dalam kategori Cukup Rendah. Sementara skor ideal keterampilan wirausaha adalah 4284 untuk 18 item pernyataan.

Skor Ideal untuk dimensi Keterampilan Wirausahaan dengan jumlah 18 pernyataan adalah 4284, sementara perolehan skor berdasarkan hasil pengolahan data dari variabel keterampilan wirausaha adalah 2176 atau 50,8\% dan skor tersebut secara kontinum dapat digambarkan sebagai berikut:

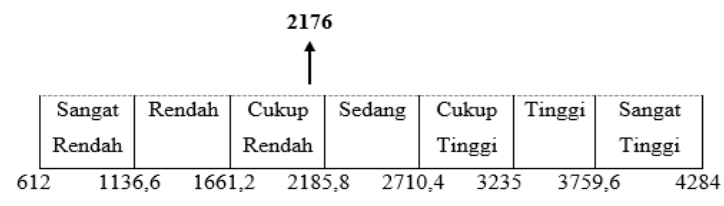

Sumber : Hasil Pengolahan Data 2018

Berdasarkan dari hasil penelitian dari penyebaran angket kepada 34 responden dapat diketahui bahwa keterampilan wirausaha pada industri lukisan di Jelekong, Kabupaten Bandung mencapai skor 2176 dari skor ideal atau jumlah maksimal, perolehan nilai responden tersebut terletak pada tingkat Cukup Rendah yaitu interval 1661,2 sampai 2185,8 . Skor tertinggi berdasarkan hasil jawaban responden terdapat pada dimensi Keterampilan Kewirausahaan Personal dengan perolehan skor 379 atau sebesar 53,1\% dari skor ideal. Sementara skor terendah berdasarkan hasil jawaban responden terdapat pada dimensi Keterampilan Manajemen Bisnis dengan perolehan skor 1063 atau sebesar 49,6\% yang terletak pada indikator Akunting dengan pernyataan 
"Kemampuan dalam pencatatan keuangan (akunting) dalam setiap transaksi".

\begin{tabular}{|c|c|c|c|c|}
\hline No & Dimensi & Total Skor & Skor Ideal & $\%$ \\
\hline \multicolumn{5}{|c|}{ Keberhasilan Usaha } \\
\hline 1 & Laba & 241 & 476 & 50,6 \\
\hline 2 & Produktivitas dan Efisiensi & 231 & 476 & 48,6 \\
\hline 3 & Daya Saing & 367 & 714 & 51,4 \\
\hline 4 & Kompetensi dan Etika Usaha & 1269 & 2380 & 53,3 \\
\hline \multirow[t]{2}{*}{5} & Terbangunnya Citra Yang Baik & 233 & 476 & 49,0 \\
\hline & Total & 2341 & 4522 & 51,8 \\
\hline
\end{tabular}

Sumber: Hasil Pengolahan Data 2018

Berdasarkan Gambar dimensi Keterampilan Wirausaha yang skor totalnya tertinggi adalah Kompetensi dan Etika Usaha dengan perolehan skor sebanyak 1269 atau 53,3\% sementara dimensi yang skor totalnya terendah adalah Produktivitas dan Efisiensi dengan perolehan skor sebanyak 231 atau $48,6 \%$. Perolehan skor berdasarkan hasil perolehan data pada variabel Keberhasilan Usaha secara keseluruhan adalah 2341, apabila di Persentasekan kedalam skor ideal maka diperoleh Persentase sebesar 51,8\% yang berarti responden menyatakan Keberhasilan Usaha pada Industri Lukisan di Jelekong, Kabupaten Bandung dalam kategori Sedang. Sementara skor ideal Keberhasilan Usaha adalah 4522 untuk 19 item pernyataan.

Skor Ideal untuk dimensi Keberhasilan Usaha dengan jumlah 19 pernyataan adalah 4522, sementara perolehan skor berdasarkan hasil pengolahan data dari variabel keberhasilan usaha adalah 2341 atau $51,8 \%$ dan skor tersebut secara kontinum dapat digambarkan sebagai berikut

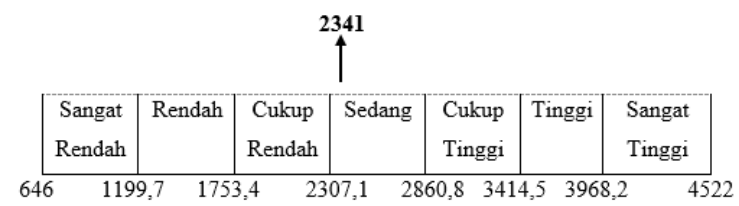

Sumber : Hasil Pengolahan Data 2018

Berdasarkan dari hasil penelitian dari penyebaran angket kepada 34 responden dapat diketahui bahwa keberhasilan usaha pada industri lukisan di Jelekong, Kabupaten Bandung mencapai skor 2341 dari skor ideal atau jumlah maksimal sebesar 4522, perolehan nilai responden tersebut terletak pada tingkat Sedang yaitu interval 2307,1 sampai 2860,8. Skor tertinggi berdasarkan hasil jawaban responden terdapat pada dimensi Kompetensi dan Etika Usaha dengan perolehan skor 1269 dari 2380 atau sebesar 53,1\% 379 atau sebesar $53,1 \%$ dari skor ideal. Sementara skor terendah berdasarkan hasil jawaban responden terdapat pada dimensi Terbangunnya Citra Yang Baik dengan perolehan skor 233 dari 476 atau sebesar 49,0\% dari skor ideal yang terletak pada indikator trust external dengan pernyataan "Kemampuan dalam menekan komplain/keluhan pelanggan"

\section{KESIMPULAN DAN REKOMENDASI}

Berdasarkan hasil penelitian yang telah dilakukan menggunakan analisis deskriptif menggunakan teknik analisis regresi linear sederhana dapat diambil kesimpulan yaitu, hasil penelitian menyatakan bahwa keterampilan wirausaha berpengaruh terhadap keberhasilan usaha.

Adanya penelitian ini diharapkan dapat membantu peneliti berikutnya dalam melakukan penelitian mengenai keterampilan wirausaha serta keberhasilan usaha dengan menggunakan indikator yang berbeda dari sumber teori yang lebih beragam, dan terhadap objek yang berbeda, karena masih banyaknya keterbatasan dalam penelitian ini, khususnya yang berkaitan dengan metode penelitian dan teknik pengumpulan data.

\section{DAFTAR PUSTAKA}

Ahmad, N. H. (2009). Dissecting Behaviours Associated with Business Failure : A Qualitative Study of SME Owners in Malaysia and Australia. Journal of Business, 5(9), 98-104.

Ali, A., Soesatyo, Y., Ekonomi, P. P., Ekonomi, J. P., Ekonomi, F., \& Surabaya, U. N. (n.d.). Analisis Perilaku Kewirausahaan Terhadap Keberhasilan Usaha Pada Usaha Kecil Menengah (UKM) Pada Pengrajin Songkok di Gresik.

Aremu, M. A., Aremu, M. A., \& Olodo, H. B. (2015). Impact of Strategic Management on the Performance of Small and Medium Scale. Journal of Sustainable Development in Africa, 17(1), 113-126.

Batsaikhan, M. (2016). Trust, Trustworthiness, and Business Success : Lab and Field Findings From Entrepreneurs. Journal of Economic and Entrepreneurship, 1, 1-13. https://doi.org/10.1111/ecin.12359

Chen, C.C., Greene, P.G. and Crick, A. (1998). Does entrepreneurial self-efficacy distinguish entrepreneurs from managers? Journal of Business Venturing, 13(4), 295-316.

Chittithaworn, C. (2011). Factors Affecting Business Success of Small \& Medium Enterprises ( SMEs ) in Thailand. Asian 
Journal of Business Management Education | Volume 3, Number 3, December 2018, page. 111-122

Social Science, 7(5), 180-190.

https://doi.org/10.5539/ass.v7n5p180

Chong, W. Y. (2012). Critical Success Factors for Small and Medium Enterprises : Perceptions of Entrepreneurs in Urban Malaysia. Journal of Busieness and Policy Research, 7(4), 204215.

Chukwujioke, K. (2013). The Relative Contribution of Management Skills to Entrepreneurial Success: A Survey of Small and Medium Enterprises (SMEs) in the Trade Sector, 7(1), 8-16.

Covin, J. \& S. D. (1991). A Conceptual Model Of Entrepreneurship As Firm Behaviour.

Entrepreneurship Theory and Practice, 16(1), 7-25.

David Smallbone. (2015). Success and Failure in New Business Start-ups. Journal of Business, 8(2), 34-47.

Fitriati, R., \& Hermiati, T. (2015). Entrepreneurial Skills and Characteristics Analysis on the Graduates of the Department of Administrative Sciences, FISIP Universitas Indonesia. Jurnal Ilmu Administrasi Dan Organisasi Journal of Administrative ScienceS \& Organization, 17(3), 262-275.

Geri, S. (2013). Relationship between Entrepreneurial Skills and Tendencies : A Research on Physical Education Students. International Journal of Business and Social Science, 4(5), 179-185.

Guido Corbetta, Morton Huse, D. R. (2004). Crossroads Of Entepreneurship. Springer Science + Business Media, Inc (Vol. 1). New York: Kluwer Academic. https://doi.org/10.1017/CBO9781107415324. 004

Hunjra, A. I. (2011). Determinants of business success of small and medium enterprises. International Journal of Business and Social Science, 2(20), 274-280. Retrieved from http://works.bepress.com/ahmed_hunjra/21/

Iverson. (2001). Physician Communication Skills: Results of a Survey of General/Family Practitioners in Newfoundland. Medical Education Online Http://www.med-Edonline.org/res00014.htm, 1-11. https://doi.org/10.3402/meo.v6i.4521

Jamil, M. M., Anwar, K., \& Kholiq, A. (2011). LUNTURNYA KESENIAN TRADISIONAL. Research Report, 5(Ii), 4151.

Katz, J. (1991). The institution and infrastructure of entrepreneurship. Entrepreneurship Theory and Practice, 85-102.
Ketchen, D. J., Ireland, R. D., \& Snow, C. C. (2007). Strategic entrepreneurship, collaborative innovation, and wealth creation. Strategic Entrepreneurship Journal, 271-395.

Mandah Chidinma. W. A. (2012). Failure of small scale businessin Nigeria: causes and solutions (a case study of selected firms in enugu state). Journal of Management, 1(1), 1-102.

Mulyadi, H. (2010). Pengaruh Motivasi dan Kompetensi Kerja Terhadap Produktivitas Kerja Karyawan pada PT. Galamedia Bandung Perkasa. Manajerial, 9(17), 97-111.

Nafuroh, S. (2013). PELATIHAN TERHADAP PENGEMBANGAN KARIR PADA PT . TIRTA INVESTAMA SURABAYA, 360369.

Nkansah. (2011). Entrepreneurship theories and Empirical research : A Summary Review of the Literature. European Journal Of Business and Management, 3(6), 1-9.

Purnama, C. \& S. (2010). Motivasi dan Kemampuan Usaha Dalam Meningkatkan Keberhasilan Usaha Industri Kecil (Studi Pada Industri Kecil Sepatu Di Jawa Timur). Jurnal Manajemen Dan Kewirausahaan, 12, $177-184$.

Pyysiainen, J. (2014). Developing the entrepreneurial skills of farmers : some myths explored. Int J Logistics Management, 12(1), 21-39. https://doi.org/10.1108/09574090910954864

Robbins. (2006). Unraveling the differential effects of motivational and skills, social, and selfmanagement measures from traditional predictors of college outcomes. Journal of Educational Psychology, 98(3), 598-616. https://doi.org/10.1037/0022-0663.98.3.598

Shabir Hyder Robert Lussier. (2016). Why Businesses Succeed or Fail : A Study on Small Businesses in Pakis. Journal of Entrepreneurship in Emerging Economies, $8(1)$.

Sukri, M. B. (2012). Determinants of Business Success, 3(November), 37-42.

Sutarna, N. (2016). PENERAPAN METODE PENUGASAN UNTUK MENINGKATKAN KEMAMPUAN MEMAHAMI PETA PADA SISWA SEKOLAH DASAR, 16(April), 3443.

Vala, L. (2017). Innovation Management Processes and Routines for Business Success and Value Creation. Journal of Management, 5(5), 471481. https://doi.org/10.17265/23282185/2017.05.011

Yonk, R. M., Harris, K., Martin, R. C., Anderson, 
Journal of Business Management Education | Volume 3, Number 3, December 2018, page. 111-122

B., Yonk, R. M., Harris, K., ... Harris, K. (2017). Exploring the case of The White Moustache Entrepreneurship and regulatory capture in the milk products industry, 41-59. https://doi.org/10.1108/JEPP-08-2016-0031

Zulkifli, R., \& Rosli, M. (2013). Entrepreneurial Orientation and Business Success of Malay Entrepreneurs: Religiosity as Moderator. Ijhssnet.Com, 3(10), 264-275. Retrieved from http://www.ijhssnet.com/journals/Vol_3_No_ 10_Special_Issue_May_2013/29.pdf\%5Cnhtt p://ijhssnet.com/journals/Vol_3_No_10_Spec ial_Issue_May_2013/29.pdf 